\title{
KUALITAS PEMBELAJARAN PENJASORKES (IMT, KEBUGARAN, DAN KEEFEKTIFAN PEMBELAJARAN) DI KOTA JAYAPURA
}

\author{
Yohanis Manfred Mandosir ${ }^{1}$, Miftah Fariz Prima Putra ${ }^{1}$
}

\begin{abstract}
Abstrak. Penelitian ini diarahkan untuk mengungkap IMT siswa, tingkat kebugaran siswa, dan keefektifan pembelajaran penjasorkes di SMA seWilayah Kota Jayapura serta untuk mengetahui hubungan antara IMT dan tingkat kebugaran dengan keefektifan pembelajaran penjasorkes.

Penelitian ini menggunakan pendekatan kuantitatif. Populasi dalam penelitian ini adalah SMA di wilayah Kota Jayapura. Dengan teknik samplingMultistages Random Sampling(MRS)diperoleh4 SMA yang sesuai dengan tujuan peneltian, yaitu: SMA Negeri 1 Jayapura, SMK Negeri 5 Jayapura, SMA Muhammadiyah Jayapura, SMA YPPK Teruna Bhakti Jayapura. Sampel guru sebanyak 4 orang sedangkan sampel siswa sebanyak 155 siswa.

Untuk pengumpulan data digunakan tiga instrumen, yaitu dokumentasi, tes, dan Formative Class Evaluation (FCE). Dokumentasi digunakan untuk mendapatkan data tentang gambaran visual siswa serta proses pembelajaran penjasorkes. Tes digunakan untuk mendapatkan data tentang IMT dan tingkat kebugaran siswa. Untuk mengetahui keefektifan pembelajaran penjasorkes akan digunakan FCE. Teknik analisis data yang digunakan ada dua, yaitu deskriptif dan regresi linier sederhana yang dikerjakan dengan bantuan program SPSS versi 21.

Hasil penelitian menemukan (1). 70\% IMT siswa SMA di wilayah Kota Jayapura berkategori normal, (2). 54,74\%tingkat kebugaran siswa SMA di wilayah Kota Jayapura berkategori kurang, (3) Keefektifan pembelajaran penjasorkes di sekolah SMA di wilayah Kota Jayapura menunjukkan hasil yang sangat baik, (4) Ada hubungan antara IMT, tingkat kebugaran dengan keefektifan pembelajaran penjasorkes.
\end{abstract}

Kata Kunci: IMT, tingkat kebugaran, keefektifan pembelajaran penjasorkes

\section{PENDAHULUAN}

Pada hari kesehatan dunia, 7 april

2002, direktur jenderal WHO Gro

Harlem Brundtland menyatakan:

"Physical activity is a fun and easy way to improve our health and well-being. It does not have to cost anything and everyone, whether young or old, can participate. It is an effective way to prevent cardiovascular disease,

diabetes, obesity and two
million deaths per years
resulting from conditions
related to physical
inactivity".

Mengingat pernyataan itu disampaikan oleh Dirjend WHO, maka tentu kredibilitas informasinya tidak diragukan. Terdapat catatan penting dari pernyataan di atas, yaitu terdapat 2 juta orang yang meningal per tahun sebagai 
akibat penyakit yang timbul karena kurang gerak (hipokinetik), seperti jantung koroner, hipertensi, obesitas, kecemasan dan depresi. Jumlah tersebut tentu tidak sedikit, di mana setiap harinya terjadi kematian \pm 5479 jiwa akibat kurang gerak.

Tidak berbeda jauh, Lutan (2008) menyebutkan bahwa $60 \%$ dari 58 juta jiwa setiap tahunnya meningal akibat peningkatan noncummunicable disease (NCD),termasuk penyakit jantung (CVD), diabetes, obesitas dan kanker lainnya;sebanyak $80 \%$ dari jumlah itu terdapat di negara berpenghasilan rendah dan menengah. Di mana 6 negara berasal dari benua Asia, yaitu: Cina, India, Indonesia, Jepang, Pakistan dan Bangladesh. Malangnya, keenam Negara tersebut masuk dalam 10 negara dengan prevalensi tertinggi.

Sejatinya, berbagai penyakit di atas dapat dicegah manakala gaya hidup dan kualitas hidup diperbaiki. Dalam konteks ini, olahraga diyakini menjadi solusi yang efektif. Memang benar bahwa olahraga bukanlah segalagalanya, namun dengan olahraga akan didapatkan banyak sekali manfaat yang diperoleh dan kebugaran tubuh adalah salah satunya.

Bertalian dengan kebugaran maka pertanyaan yang relevan diajukan adalah bagaimanakah tingkat kebugaran masyarakat Indonesia? Berdasarkan data Sport Development Index (SDI) tahun 2006 diketahui bahwa tingkat kebugaran masyarakat Indonesia masih jauh dari kata memuaskan.

Pertanyaannya kemudian, bagaimana dengan kondisi di Papua? Menggunakandata SDI tahun 2004 diketahui bahwa tingkat kebugaran masyarakat (anak-anak, remaja, dan dewasa) di tiga wilayah Papua masih dalam kategori rendah ; Kota Jayapura dengan indeks kebugaran 0,449, Jayapura 0,428 dan Keerom 0,320. Nilai yang didapat ini termasuk dalam kategori rendah. Itu artinya, tingkat kebugaran masyarakat Papua masih jauh dari harapan. Padahal, kebugaranmenjadi faktor yang sangat penting dalam upaya meningkatkan kualitas serta produktifitas masyarakat, yang selanjutnya akan berdampak pada naiknya kesejahteraan masyarakat. Coba bayangkan! Apa jadinya bila suatu masyarakat kondisi tubuhnya cepat lelah dan mudah mengantuk? Tentu mereka tidak akan bisa produktif dalam bekerja dan berkarya. Bila itu yang terjadi maka alih-alih masyarakat menjadi maju, yang ada justru mereka akan menjadi beban Negara dan menghambat kemajuan.

Pendidikan Jasmani, Olahraga dan Kesehatan (Penjasorkes) diyakini sebagai instrumen yang efektif guna membudayakan olahraga dan/atau aktivitas fisik di masyarakat, khususnya pada kalangan remaja. Memang betul bahwa penjasorkeshanya sebuah mata pelajaran, namun melalui penjasorkes budaya hidup sehat serta kebugaran masyarakat yang lebih baik sangat mungkin bisa tercapai, setidaknya pada siswa (kalangan remaja).

Mendasarkan pada uraian di atas, maka dipandang perlu untuk mengungkap tentang Indeks Masa Tubuh (IMT) siswa, tingkat kebugaran siswa, serta keefektifan pembelajaran penjasorkes di lapangan. Dengan demikian akan diketahui kondisidi lapangan yang sebenarnya tentang kualitas pembelajaran penjasorkes.

Tujuan penelitia ini adalah untuk untuk mengungkap IMT siswa, tingkat kebugaran siswa, dan keefektifan pembelajaran penjasorkes di SMA seKota Jayapura serta untuk mengetahui hubungan antara IMT dan tingkat kebugaran dengan keefektifan pembelajaran penjasorkes. Tinjauan Pustaka. 
Tinjauan Pustaka. Indeks Massa Tubuh (IMT) adalah nilai yang diambil dari perhitungan antara berat badan (BB) dan tinggi badan (TB) seseorang. IMT dipercayai dapat menjadi indikator atau mengambarkan kadar adipositas dalam tubuh seseorang. IMT tidak mengukur lemak tubuh secara langsung, tetapi penelitian menunjukkan bahwa IMT berkorelasi dengan pengukuran secara langsung lemak tubuh seperti underwater weighing dan dual energy $x$-ray absorbtiometry (Grummer-Strawn LM et al., 2002). IMT merupakan altenatif untuk tindakan pengukuran lemak tubuh karena murah serta metode skrining kategori berat badan yang mudah dilakukan. Untuk mengetahui nilai IMT ini, dapat dihitung dengan rumus berikut:

Menurut rumus metrik:

$$
\mathrm{IMT}=\frac{\text { Berat badan }(\mathrm{Kg})}{[\text { Tinggi badan }(\mathrm{m})]}
$$

Tingkat Kebugaran adalah kemampuan tubuh seseorang untuk melakukan tugas dan pekerjaan seharihari tanpa menimbulkan kelelahan yang berarti, sehingga tubuh masih memiliki simpanan tenaga untuk mengatasi beban tambahan (Kusmaedi, 2008:93).

Senada dengan pendapat tersebut, Giriwijoyo (2002:23) mengungkapkan, kebugaran jasmani adalah keadaan kemampuan jasmani yang dapat menyesuaikan fungsi alat alat tubuhnya terhadap tugas jasmani tertentu atau terhadap keadaan lingkungan yang harus diatasi dengan cara yang efisien, tanpa kelelahan yang berlebihan dan telah pulih sempurna sebelum dating tugas yang sama pada esok harinya.

Pembinaan kebugaran jasmani sangat berpengaruh bagi siswa guna menunjang proses pembelajaran di sekolah, serta aktivitas fisik lain diluar sekolah. Berdasarkan beberapa pendapat diatas dapat disimpulkan bahwa kebugaran jasmani adalah kualitas kemampuan tubuh seseorang untuk melakukan aktivitas sehari-hari tanpa mengalami suatu kelelahan yangberlebihan dan masih dapat menikmati waktu luang serta selalu siap untuk melakukan aktivitas fisik lainnya. Dalam aktivitas sehari-hari, kebugaran jasmani menggambarkan keadaan tubuh seseorang selain mampu mengerjakan pekerjaan rutin harian juga masih sanggup melakukan aktivitas fisik lainnya.

Kebugaran jasmani terdiri dari beberapa komponen seperti yang dikemukakan oleh Rusli Lutan (2001:8) dalam F Suharjana (2008:66) bahwa "komponen kebugaran jasmani terdiri dari kebugaran jasmani yang berkaitan dengan kesehatan, yang mengandung unsur empat pokok yaitu: kekuatan otot, daya tahan otot, daya tahan aerobik, dan fleksibilitas, serta kebugaran jasmani yang berkaitan dengan performance. Untuk kebugaran yang berkaitan denga performace mengandung unsur: koordinasi, kelincahan, kecepatan gerak, dan keseimbangan.”

Kebugaran jasmani seseorang sangat ditentukan dengan beberapa faktor sebagai berikut, yakni : faktor umur, keturunan, dan jenis kelamin, serta pencapaian pola hidup sehat yang meliputi pola mengatur makanan, mengatur istirahat, dan mengatur aktivitas olahraga.

Keefektifan pembelajaran. Efektivitas dalam pengertian secara umum adalah "kemampuan berdaya guna dalam mselaksanakan sesuatu pekerjaan sehingga menghasilkan hasil guna (efisien) yang maksimal".

Menurut Harry Firman (dalam skripsi Wiwi Irjanty Kentjil: 2010: 9) keefektifan program pembelajaran di tandai dengan ciri-ciri sebagai berikut : 
a. Berhasil menghantarkan siswa mencapai tujuan-tujuan instruksional yang telah ditetapkan, b. Memberikan pengalaman belajar yang atraktif, melibatkan siswa secara aktif sehingga menunjang pencapaian tujuan instruksional, c. Memiliki sarana-sarana yang menunjang proses belajar mengajar.

Dari penjelasan di atas dapat disimpulkan bahwa proram pembelajaran yang baik adalah bagimana guru berhasil menghantarkan anak didiknya untuk mendapatkan pengetahuan dan memberikan pengalaman belajar yang antraktif. Berdasarkan ciri pembelajaran efektif seperti yang digambarkan di atas, keefektifan program pembelajaran tidak hanya ditinjau dari tingkat prestasi belajar. melainkan harus pula ditinjau dari segi proses dan sarana penunjang. Aspek hasil meliputi tinjauan terhadap hasil belajar siswa setelah mengikuti program pembelajaran yang mencakup kemampuan kognitif, afektif, dan fsikomotorik. Aspek proses meliputi pengamatan terhadap keterampilan siswa, motivasi, respon, kerjasama, partisipasi aktif, tingkat kesulitan pada penggunaan media, waktu serta teknik pemecahan masalah yang ditempuh siswa saat kegiatan belajar mengajar berlangsung aspek sarana penunjang meliputi tinjauan-tinjauan terhadap fasilitas fisik dan bahan serta sumber yang diperlukan siswa dalam proses belajar mengajar seperti ruang kelas, laboratorium, media pembelajaran dan buku-buku teks.

Terdapat beberapa faktor-faktor yang mempengaruhi efektivitas belajar di sekolah, yaitu:(1) Strategi dan Metode Pembelajaran, (2) Materi Pembelajaran, (3) Media Pembelajaran, (4) Evaluasi Pembelajaran, dan (5) Gaya Mengajar pendidik.

\section{METODE}

Penelitian ini menggunakan pendekatan kuantitatif yang mengabungkan jenis penelitian deskriptif dan korelasional. Variabel bebas dalam penelitian ini adalah IMT siswa dan tingkat kebugaran siswa; sedangkan variabel terikatnya adalah keefektifan pembelajaran penjasorkes.

Berdasarkan rumusan pertanyaan serta tujuan penelitian maka populasi dalam penelitian ini adalah seluruh sekolah tingkat SMA di wilayah Kota Jayapura. Dengan menggunakan teknik sampling Multistages Random Sampling (MRS) di dapat 4 SMA yang sesuai dengan tujuan peneltian, yaitu: SMA Negeri 1 Jayapura, SMK Negeri 5 Jayapura, SMA Muhammadiyah Jayapura, SMA YPPK Teruna Bhakti Jayapura. Sampel guru sebanyak 4 orang sedangkan sampel siswa sebanyak 137 siswa.

Instrumen Penelitian. Dalam penelitian ini, untuk mengumpulkan data penelitian digunakan tiga instrumen, yaitu dokumentasi, tes, dan Formative Class Evaluation (FCE). Dokumentasi digunakan untuk mendapatkan data tentang gambaran visual siswa serta proses pembelajaran penjasorkes. Tes digunakan untuk mendapatkan data tentang IMT dan tingkat kebugaran siswa. IMT akan diketahui dengan melakukan pengkuran berat badan dan tinggi badan; sedangkan tingkat kebugaran akan diketahui dengan menggunakan Tes Kesegaran Jasmani Indonesia (TKJI). Untuk mengetahui keefektifan pembelajaran penjasorkes akan digunakan FCE. Instrumen tersebut dikembangakan oleh Takahashi et al. pada tahun 1994 di Jepang.

Teknik analisis data yang digunakan ada dua, yaitu deskriptif dan regresi linier sederhana. Analisis deskriptif digunakan untuk memaparkan data latar 
IMT, tingkat kebugaran, dan keefektifan pembelajaran. Teknik analisis regresi linier sederhana akan digunakan untuk mengetahui ada tidaknya hubungan antara IMT dan tingkat kebugaran dengan keefektifan pembelajaran. Semua penghitungan akan dibantu dengan menggunakan program SPSS versi 21 .

\section{HASIL DAN PEMBAHASAN}

Berdasarkan data yang dikumpulkan di lapangan dan hasil analisis yang dilakukan oleh penelitian sebagai berikut :

Indeks Massa Tubuh (IMT) Siswa. Nilai yang diambil dari perhitungan antara berat badan (BB) dan tinggi badan (TB) seseorang. IMT dipercayai dapat menjadi indikator atau menggambarkan kadar adipositas dalam tubuh seseorang. Hasil pengukuran IMT terhadap siswa-siswa SMA di Kota Jayapura tampak seperti gambar $1 \mathrm{di}$ bawah ini:

Tabel 1. IMT Siswa

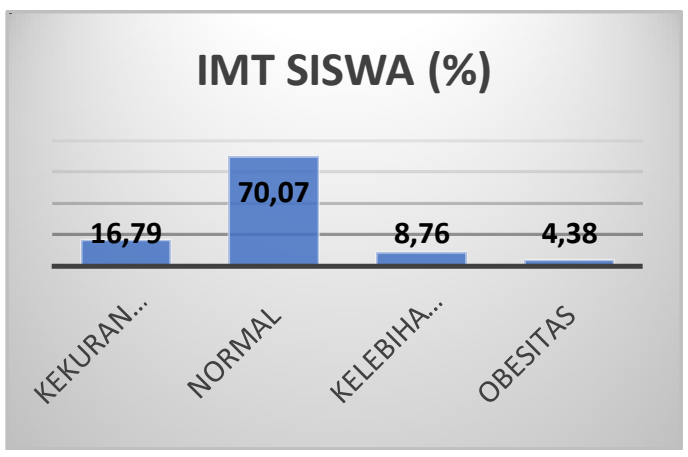

Sumber: Hasil pengolahan data

Dari tabel 1 di atas tampak bahwa sebesar 70,07\% (96) siswa memiliki IMT normal. Sebesar 16,79\% (23) siswa IMT-nya berkategori Kekurangan Berat Badan. Untuk yang berkategori Kelebihan Berat Badan sebesar 8,76\% (12), dan untuk yang obesitas sebesar $4,38 \%$ (6). Dengan data tersebut maka dapat dikatakan bahwa rata-ratasiswa- siswi SMA se- Kota Jayapura memiliki IMT normal

Tingkat Kebugaran Siswa dipahami dalam tulisan ini sebagai kemampuan tubuh untuk melakukan aktifitas seharihari tanpa mengalami rasa kelelahan yang berarti. Hasil tingat kebugaran siswa yang diukur dengan Tes Kebugaran Jasmani Indonesia (TKJI) tampak seperti gambar 2 di bawah ini:

Tabel 2. Tingkat Kebugaran Siswa

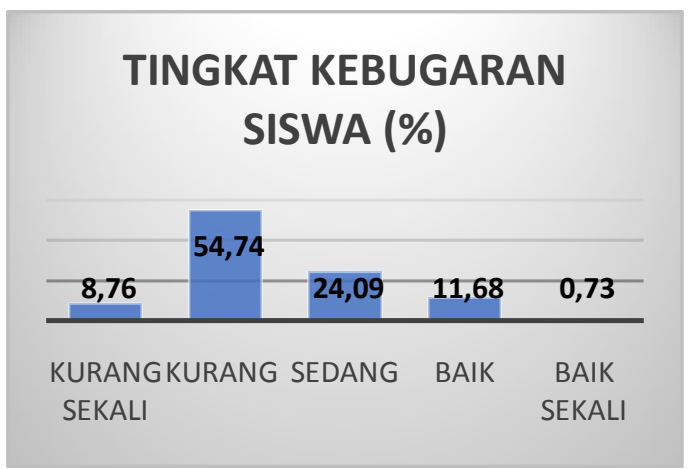

Sumber: Hasil pengolahan data

Dari tabel 2 di atas tampak secara berurut bahwa sebesar 54,74\% (75) siswa kategori tingkat kebugaranya kurang. Yang tingkat kebugaranya berkategori sedang sebanyak 24,09\% (24) siswa, kategori baik sebanyak $11,68 \%$ (16) siswa, kategori kurang sekali sebesar 8,76 (12) siswa, dan hanya 0,73 (1) yang memiliki tingkat kebugaran baik sekali. Melalui data tersebut dapat dikatakan bahwa rata-rata siswa-siswi SMA di Wilayah Jayapura memiliki tingkat kebugaran yang kurang.

Keefektivan Pembelajaran
Penjasorkes merupakan tingkat
keefektifan suatu pelajaran penjasorkes
yang dilakukan oleh guru. Untuk
melihat keefektifan pembelajaran
penjasorkes, studi ini akan
menggunakan instrumen standar yang
biasa digunakan dalam mata pelajaran


penjasorkes. Instrument ini disebut dengan Formative Class Evaluation (FCE). Melalui FCE akan didapat respon siswa yang meliputi aspek: result (hasil), volition (kemauan), method (metode), dan cooperation (kerjasama) dalam konteks pembelajaran penjasorkes. Berdasarkan hasil pengolahan data yang dilakukan peneliti dapat dibuat tabel keefektifan pembelajaran Penjasorkes sebagaiman terlihat pada gambar 3 di bawah ini :

\section{Tabel 3. Nilai Rata-rata FCE}

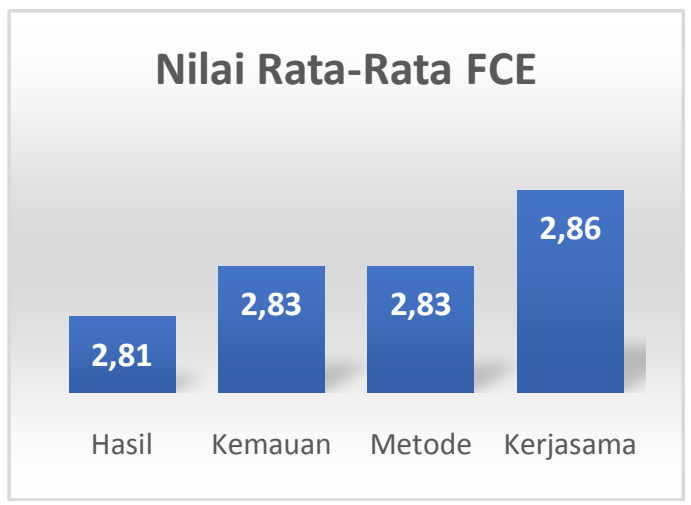

Dari tabel di atas di atas tampak bahwa nilai indikator secara berurutan adalah indikator kerjasama (2.86), kemauan dan metode (2.83), kemudian indikator hasil (2.81).

\section{Analisis Regresi Linear Berganda}

Untuk mengetahui ada tidaknya hubungan antar variabel maka akan digunakan teknik analisis regresi berganda, berikut adalah hasilnya :

\section{Tabel 4. Hasil Analisis Regresi}

\begin{tabular}{c|c|c|c|c}
$\mathrm{R}$ & $\mathrm{R}^{2}$ & $\begin{array}{c}\text { Persamaan } \\
\text { Garis } \\
\text { Regresi }\end{array}$ & $\mathrm{F}$ & $\begin{array}{c}\mathrm{P} \\
\text { Value }\end{array}$ \\
\hline 0.26 & 0.06 & $\begin{array}{c}\mathrm{Y}=2.460 \\
+0.010 \\
\left(\mathrm{X}_{1}\right)+ \\
0.012\left(\mathrm{X}_{2}\right)\end{array}$ & 4,906 & 0,009
\end{tabular}

Sumber : Hasil Pengelolaan Data
Dari tabel di atas tampak bahwa nilai $r=0,261$ yang bermakna bahwa hubungan yang terjadi di antara variable bersifat lemah. Hal tersebut didukung oleh Nilai koefisien dengan determinasi 0,068. Artinya, persamaan garis regresi yang kita peroleh dapat menerangkan $0,68 \%$ variasi keefektifan pembelajaran penjasorkes. Dengan kata lain, persamaan garis yang diperoleh kurang baik untuk menjelaskan variabel keefektifan pembelajaran penjasorkes. Dari teknik analisis tersebut didapat persamaan garis regresi sebagai berikut: $\mathrm{Y}=2.460+0.010\left(\mathrm{X}_{1}\right)+0.012\left(\mathrm{X}_{2}\right)$.

Dalam pengujian hipotesis didapatkan nilai $F$ sebesar 4,906 dengan nilai $P$ Value sebesar 0,009 atau $P$ Value $<0,05 \quad(0,009<\quad 0,05)$. Artinya hipotesis kerja yang menyatakan "ada hubungan antara IMT, tingkat kebugaran dengan keefektifan pebelajaran penjasorkes" diterima.

\section{PEMBAHASAN}

Indeks Massa Tubuh (IMT).Hasil penelitian menunjukan bahwa sebesar $70,07 \%$ (96) siswa memiliki IMT normal. Kemudian, siswa yang IMT-nya berkategori Kekurangan Berat Badan sebesar 16,79\% (23), yang Kelebihan Berat Badan sebesar 8,76\% (12), dan untuk yang obesitas sebesar $4,38 \%$ (6). Dengan data tersebut maka dapat dikatakan bahwa rata-rata siswasiswi SMA se-Kota Jayapura memiliki IMT normal.

Hasil tersebut mengindikasikan bahwa apabila dilihat berdasarkan nilai tinggi dan berat badan maka para siswasiswi di Kota Jayapura rata-rata IMTnya normal. Hasil diskusi yag dilakukan dengan siswa-siswi ketika pengambila data dilakukan menyebutkan bahwa remaja putri/putra di Kota Jayapura menghindari keadaan kelebihan berat badan apalagi obesitas. Alasan ini yang menyebabkan remaja putri/putra akan 
melakukan apasaja untuk menekan pertambahan berat badan termasuk pembatasan terhadap jumlah makanan yang masuk ke dalam tubuh.

Tingkat Kebugaran Jasmani. Dari hasil penelitian tampak bahwa sebesar 54,74\% (75) siswa kategori tingkat kebugaranya kurang. Yang tingkat kebugaranya berkategori sedang sebanyak 24,09\% (24) siswa, kategori baik sebanyak $11,68 \%$ (16) siswa, kategori kurang sekali sebesar 8,76 (12) siswa, dan hanya 0,73 (1) yang memiliki tingkat kebugaran baik sekali. Melalui data tersebut dapat dikatakan bahwa rata-rata siswa-siswi SMA di Kota Jayapura memiliki tingkat kebugaran yang kurang.

Faktor utama yang berpengaruh langsung terhadap kebugaran jasmani adalah aktivitas fisik yang teratur dan terukur. Tingkat kebugaran yang kurang pada siswa/siswi SMA di Kota Jayapura disebabkan oleh kurangnya aktivitas fisik. Berdasarkan hasil diskusi degan responden diketahui bahwa umumnya mereka jarang melakukan kegiatan olahraga, terutama pelajar perempuan. Kegiatan olahraga hanya dilakukan pada saat jam pelajaran penjasorkes di sekolah yang hanya ada seminggu sekali.

Keefektivan Pembelajaran

Penjasorkes. Hasil penelitian menunjukkan bahwa nilai indikator secara berurutan adalah indikator kerjasama (2.86), kemauan dan metode (2.83) kemudian hasil (2.81). Berikut akan diuraikan hasil skor FCE di atas dan maknanya secara keseluruhan.

1). Pada indikator "Hasil (Result)" nilai rata-rata skor FCE keseluruhan siswa sebesar 2,81. Menurut kriteria Takahashi nilai tersebut dapat dikategorikan nilai 5, yang bermakna Sangat Baik.

2). Pada indikator "Kemauan (Volition)" nilai rata-rata skor
FCE keseluruhan siswa sebesar 2,83. Menurut kriteria Takahashi nilai tersebut dapat dikategorikan nilai 4, yang bermakna Baik.

3). Pada indikator "Metode (Method)"nilai rata-rata skor FCE keseluruhan siswa sebesar 2,83. Menurut kriteria Takahashi nilai tersebut dapat dikategorikan nilai 5, yang bermakna Sangat Baik..

4). Pada indikator "Kerjasama (Cooperation)"nilai rata-rata skor FCE keseluruhan siswa sebesar 2,83. Menurut kriteria Takahashi nilai tersebut dapat dikategorikan nilai 5, yang bermakna Sangat Baik..

5). Hasil FCE Keseluruhan (Total) menunjukan nilai rata-rata keseluruhan siswa sebesar 2,83. Menurut kriteria Takahashi nilai tersebut dapat dikategorikan nilai 5, yang bermakna Sangat Baik.

Berdasarkan hasil diskusi
diketahui bahwa pembelajaran
penjasorkes adalah pembelajaran yang
menyenangkan bagi siswa SMA karena
metode pembelajaran yang berbeda di
mana pembelajaran dilakukan di luar
kelas. Selain itu,kerjasama dan
kebersamaan antar siswa/siswi dapat
ditumbuhkembangkan melalui
pembelajaran ini. Dengan begitu, para
sswa-siswi merasa senang dan antusias
ketika mengikuti pembelajaran
penjasorkes.

Hubungan Antar Variabel. Berdasarkan hasil uji regresi linear berganda diketahui bahwa nilai $\mathrm{r}=$ 0,261 yang bararti hubungan yang terjadi di antara variabel bersifat lemah. Hal tersebut didukung oleh Nilai koefisien dengan determinasi 0,068. Artinya, persamaan garis regresi yang diperoleh dapat menerangkan $0,68 \%$ variasi keefektifan pembelajaran penjasorkes. Dengan kata lain, persamaan garis yang diperoleh kurang 
baik untuk menjelaskan variabel keefektifan pembelajaran penjasorkes. Dari teknik analisis tersebut didapat persamaan garis regresi sebagai berikut: $\mathrm{Y}=2.460+0.010\left(\mathrm{X}_{1}\right)+0.012\left(\mathrm{X}_{2}\right)$

Hasil di atas mengindikasikan bahwa terdapat hubungan di antara variabel tapi karena hubungannya bersifat lemah maka variabel IMT kurang kuat untuk dapat menjadi variabel prediktor bagi variabel keefektifan pembelajaran. Hal yang sama juga terjadi pada variabel tingkat kebugaran, yaitu lemah untuk dijadikan variabel prediktor pada variabel keefektifan pembelejaran.

\section{PENUTUP}

Kesimpulan. Berdasarkan hasil di atas maka dapat disimpulkan sebagai berikut:

1. $70 \%$ IMT siswa SMA di wilayah Kota Jayapura berkategori normal;

2. $54,74 \%$ tingkat kebugaran siswa SMA di wilayah Kota Jayapura berkategori kurang;

3. Keefektifan pembelajaran penjasorkes di sekolah SMA di wilayah Kota Jayapura menunjukkan hasil yang sangat baik;

4. Ada hubungan antara IMT, tingkat kebugaran dengan keefektifan pembelajaran penjasorkes.

Saran. Mendasarkan pada simpulan penelitian di atas maka saran yang diajukan dalam penelitian ini adalah sebagai berikut:

1. Tingkat kebugaran siswa perlu mendapat perhatian dari guruguru penjasorkes untuk ditingkatkan;
2. Untuk penelitian lanjutan hendaknya dilakukan dengan cakupan subyek dan wilayah yang lebih luas di wilayah Papua.

\section{DAFTAR RUJUKAN}

Mutohir, T.C. \& Maksum, Ali. Sport development index: konsep, metodologi, dan aplikasi. Jakarta: PT. Indeks, 2007.

Lutan, R. (2008). Trend perkembangan olahraga dari perspektif glabal: inovasi \& pengetahuan lintas disiplin. Makalah disampaikan dalam"konvensi nasional pendidikan jasmani, pendidikan kesehatan, rekreasi, olahraga dan tari" tanggal 24 november 2008 diUPI, Bandung, Indonesia.

Suherman, Wawan. (2007). Perlunya Pendidikan Jasmani Bagi Anak. (Online). Tersedia: http://www.matabumi.com/pend idikan/perlunya-pendidikanjasmani-bagi-anak. (diakses tanggal 15 Desember 2007.

Suroto., dkk. (2007). Laporan akhir model pembelajaran penjasorkes inovatif untuk sekolah dasar IU-07-01. Jakarta: Balitbang, Puslitjaknov, Depdiknas.

Suroto. (2008).Keaktifan gerak siswa sekolah dasar dalam pendidikan jasmani sekolah dasar. Makalah disampaikan dalam konvensi nasional pendidikan jasmani, pendidikan kesehatan, rekreasi, olahraga,tanggal24 november 2008, di UPI Bandung, Indonesia.

Mahendra, Agus. (2007). Hakikat Pendidikan Jasmani. (Online). Tersedia: http://pbprimaciptautama.blogsp ot.com/2007/06/falsafah- 
pendidikan-jasmani.html

(diakses tanggal 10 Nopember 2007).

(2007). Pendidikan Jasmani:

Tidak Menanam, Tidak Menuai.

(Online). Tersedia:

www.setjen.depdiknas.go.id/pusjas/inde x.php. (diakses tanggal 12 Agustus

2007). 